\title{
Feminist Ideology in Pramoedya Ananta Toer's Novel Entitled Bumi Manusia
}

\author{
Sanusi Sunawar Hery Murti* \\ Indonesian Language and Literature Education of Graduate School \\ Universitas Negeri Yogyakarta \\ Yogyakarta, Indonesia \\ sanusisunawar.2018@student.uny.ac.id
}

\begin{abstract}
Bumi Manusia" novel talks about women who are enthusiastic and passionate. Pramoedya Ananta Toer delivers feminist ideology and also past inequalities between women and men. This novel also impresses the upheaval related to the society and colonization state. The type of this research is a qualitative one by using descriptive methods. The researcher uses words as data sources. The data sources of this research come from the "Bumi Manusia" novel text made by Pramoedya Ananta Toer. The research instrument is the researcher himself because the researcher is the data collection tool as well as being the data analyzer. "Bumi Manusia" novel provides descriptions of Nyai Ontosoroh which can be used by the author to convey feminist ideology according to the result of the analysis. This aims to reconstruct the position of women in society. "Bumi Manusia" novel describes the struggle of third-class women as subjects.
\end{abstract}

Keywords: ideology, feminist, woman, novel, Pramoedya

\section{INTRODUCTION}

Literary work is created by human based on their sense and desire. Values of elegance and life discretion are also included in literary work besides giving entertainment Readers can discover the life values, manners, belief, and the life viewpoint of others or society through literary works. Therefore, literary work and human have an inseparable relationship. Literature is a reflection of human life through all its expressions. Life problems are considered as inspiration for the author to express himself with the media which is literary work itself.

As a media, literary work becomes very interesting because they are imaginative. It means literary work occurs as a result of new discovery. The new discovery is arranged based on the power of imagination to create a new world. Moreover, imaginative literary work can affect the soul of a reader. Readers feel the events on the story of the novel as if they were carried away (Wellek, 2009:59).

Reading a good novel is like playing a game with challenging difficulties. Therefore, it is completely different with the trivial game which just ignore the rules (Stanton, 2007:27). The purpose of this opinion, especially while reading fiction, is to give deep understanding so that people are able to capture something that is conveyed by the author. Hence, understanding a novel is as same as living a fantasy world created by the writer. Literary work is not something empty, instead the world in literary work can be used as a way to see the state of society where literary work was born and grow.

Thus, it is very logical that literary work is a means of cultural representation, like in literary work which has gender relation

\author{
Suminto A. Sayuti \\ Indonesian Language and Literature Education \\ of Graduate School \\ Universitas Negeri Yogyakart \\ Yogyakarta, Indonesia \\ suminto_sayuti@uny.ac.id
}

and routine. The existence of literary work can also create new gender stereotypes and more indicative of gender freedom. So that, literary work with gender studies requires a feminist literary criticism approach (Hollows, 2010:13). Feminist literary criticism can be understood as an attempt to expose women according to sexual stereotypes, both in literature and in literary criticism. Furthermore, it also exposes inadequate schools and methods that have been used to study women's writing unfairly and insensitively (Hollows, 2010:39).

The article which is relevant to this research is entitled "Deconstructing Gender and Development for Identities of Women" (2007) published in an international journal namely "International Journal of Social Welfare" written by Shweta Singh. This article discusses the gender and development paradigm which has gained a central place in many studies especially about development impact and modernization of women in developing societies. It also discusses the social development of gender hierarchies and gender itself. On the other hand, it highlights the potential of women as economic assets and the social forces that often refuse the women contribution.

The second related article to this research is entitled "Men and The 1970's British Women's Liberation Movement" (2013) that was published in an international journal namely "The Historical Journal" written by Nicholas Owen. This article discusses the causes and effects of the British women's liberation movement in 1970. Besides, it also discusses men's responses to the movement and self-organization in men's groups. The article also explains that the women liberation movement is very committed to organizational autonomy and self sufficiency. It is believed that the demands of the oppressed groups must be formulated and presented directly by the oppressed groups themselves. Therefore, there is a need for better education for women. The association of those articles with this research is the use of liberal feminism theory as a foundation. In addition, they equally fight for women's education as women's rights. The difference is that this research is deeper into women's selfpotential, while the article focuses on the women's liberation movement and men's responses to the movement.

The study results a form of patriarchal culture description that is detrimental to women and feminist ideology in the "Bumi Manusia" novel. This will be the subject of character education. It means this research is the first step to continue the next research on strengthening gender equality of character education for junior and senior high school students. Moreover, it is very possible for character education at the college level. This 
research will also provide awareness of the feminist ideology struggle continuously and consistently in the field of work, justice, and other fields of life. Therefore, the essence of character education is achieved, which is the attainment of a holistic education that connects the moral dimension with the social realm in the lives of students as the reliable foundation for the truth principle (Raharjo, 2010:11).

\section{RESEARCH METHOD}

This research is a qualitative research with descriptive method or content analysis technique. With this content analysis technique, conclusions can be drawn after identifying specific characteristics in a text systematically and objectively (Bogdan, 1993:85). Descriptive qualitative uses data not in the form of numbers or coefficients about the relationship of variables. Data collected in the form of word quotes, sentences, and discourse from the "Bumi Manusia" Novel.

The data in this study are written words or sentences that lead to feminist ideology, especially those that come in direct contact with the female characters in the "Bumi Manusia" Novel. The data source of this research is the "Bumi Manusia" Novel by Pramoedya Ananta Toer published by PT. Lantern Dipantara in the sixteenth print in 2005. This novel consists of 535 pages.

\section{RESEARCH RESULTS}

a) Feminist Ideology

Ideology as a collection of ideas which influence many aspects in life. A general definition says that ideology is a way of thinking to regulate and improve society (Adams, 2004:58).

Feminist ideology combines the doctrine of equality for women with an ideology of social transformation. It aims to create a world for women. Because of the gender factors, women experience injustice. The ultimate is to achieve dynamic balance so that the society will not marginalize women (Sugihastuti, 2000:44). Feminism can also be achieved by replacing feminine values and behavior with masculine values to get gender equality in the order of social society (Adams, 2004:77).

Women bring up the movement for the equal rights with men. Women also demand to get their rights fairly. In general, these are because women feel inadequate in many fields, like in the social, occupational, educational, and political fields. (Mills, 2009:33).

In general, feminist literary criticism is a means to observe literary discourse based on social knowledge and humanity. This source of this criticism is from feminism itself with a basic of sex and gender understanding. Sex is permanently unchanged, while gender is an inherent trait for men and women who are socially and culturally constructed.

In some cases of literary work, there is a lower position of women than men because of patriarchy - the domination of men in all social relations (Abrams, 1999:88). In a conductive manner, sometimes culture make women become inferior. Thus, there is a binary opposition which becomes the goal of feminism including in literary studies (Arivia, 2006:18-19).
Sara Mills's theory emphasizes more on discrimination against women in texts, like in novels, photographic images, or news. In texts, women tend to be shown as wrong and marginal party compared to men. The discourse analysis shows that women are depicted and marginalized in a news text., as well as in the form of marginalization (Tong, 2006:99).

In the literature study, feminism shifts the focus from the masculine reality into feminine reality. Feminist literary criticism against literary works is used as material for women's freedom movements and feminist ideas socialization. In summary, feminist literary criticism disputes assumptions about women based on certain understandings associated with the nature and the raising of women certain issues (Humm, 2007: 89).

Feminism seeks the realization of an ideal society with women as one aspect in it. This can be traced by both female writers and male writers who care about the fate of women. The understanding of ideology can help people to analyze and find images of feminist ideology in "Bumi Manusia" novel.

There are two things that need to be considered in the analysis. First, social actors which have specific positions in the news, i.e. who is positioned as an interpreter to interpret the events and what the consequences are. Second, how the reader is positioned in the news. News here are interpreted as the result of negotiations between the writer and the reader. It means that the audience is as same as what the writers imagine to write (Mills, 2009: 102).

The choice to which group is positioned as the narrator makes the event appears in the perspective and interest of the narrator. This has close relation with ideology. Positioning one group will make that group has higher position among the other groups. Therefore, it becomes the means for marginalization. Usually, marginalized groups are groups that do not have access to the media. That is why they are displayed poorly. in the text as objects. The description of them is displayed by other parties with bias and prejudice, not with those who speak and describe themselves. (Owen, 2013:4).

\section{b) Feminist Ideology in "Bumi Manusia" novel}

There are many developed feminist persons nowadays. They aim to make women as rational beings, to make women deserve their rights, and to determine women as equals as men (Rutven, 1990: 111).

"Bumi Manusia" novel has pictures of the post-colonial feminist ideology. This flow is based on the idea that the women experience in the third world countries or in former colonies is different from the women experience in the first state. "Bumi Manusi" novel took the setting in the early 20th century, precisely around 1898 when Indonesia was called Hindia Belanda in Dutch colony.

Postcolonial feminist ideology can be traced from the words, actions, and the main character's thoughts about himself and other figures. Postcolonial feminist ideology assumes that women in the third world bear the burden of oppression between nations, ethnicities, races, religion, and especially gender. The 
main focus of this school is to illustrate that occupation plays a role in the women oppression. Occupation happens through physical, knowledge, values, perspectives, and mentality of the society which becomes the concern of post-colonial feminism itself.

Figures in "Bumi Manusia" novel are portrayed as critical figures who care about the fate of women. Feminist spirit cannot be pinned to female figures, but also to male figures.

\footnotetext{
"You are slumber." "I'm not going to be a regent." "Listen to me first." "I will make a question: Hi phylogynik, womanizer, lady killer, where is your harem?" "Seems you see me as an uncivilized Javanese." "Was there a Javanese, also a regent, wasn't a womanizer?" (Toer, 2003:23).
}

The theme a proof the background of the structure that characterizes the colonial period (Soekiman, 2011:59). It is a prove that indeed colonialism gives a negative impact for women.

Above is Minke's conversation with Robert Suurhof. Robert calls Minke as a basket and a land crocodile. Then, he asks Minke where his harem is. Minke denies and issues his saying that only uncivilized Javanese who has such behavior. It is strengthened by the practice of concubines, harems, and prostitution long before the colonialism (Singh, 2007:8).

Pramoedya presents feminist thought through his characters. In the other hand, men who have mistresses are men who don't have norms of modesty. This is analogous to the feminist goal of wanting to eliminate oppression and abuse against women. Therefore, Minke calls those who still have that kind of manner as not civilized Javanese people rather than uncivilized ones. This indicates that the harsh reality can be changed by providing understanding of women who have the same living rights as men.

A maidservant served chocolate milk and cake. She came with no scrambling as to the native master. Otherwise she looked at me to express her amazement. It was impossible happening to a native master. She ought to bow and bow. And what a beautiful life without scrambling before another people (Toer, 2003:35).

The quote above is taken from Minke's part of story when he is inside Nyai Ontosoroh's house. At the end of the quote, Minke expresses his feelings about how beautiful life is if it does not have to degrade themselves before others. In accordance with the above context, the female servant represents the working women of that time.

"Bumi Manusia" novel fight against the women degrading culture. It can be seen in the crawling practice like what the female servants do. Minke seems to wish that all homeworkers get freedom so that they do not have to maintain the crawling practice. Crawling is a symbol of being weak because people who crawl must put themselves lower than the others. For Europeans like Minke, crawling is inappropriate because it violates the value of equality especially gender equality (Djajanegara, 2000:71).

The quote above also reinforces that there are differences in the treatment of women in third world countries and first world countries. The treatment of women in first world countries or independent countries is exemplified by European families. They treat their female workers freely and have their rights respected as human beings. The treatment of women in the third world is represented through the treatment of female servants in indigenous families. They are positioned as individual workers with full loyalty.

"Are you surprised to see a working woman?" I nodded. She stared at me as if wanted to interpret my astonishment (Toer, 2003:44).

Minke's astonishment continues when there is a feeling of wonder to see female workers who work at the Nyai Ontosoroh company. In colonial times, working is owned by men, not by women. Pramoedya provides an example of European culture about accepting and allowing women to have their right to work. Minke has feminist ideology because he believes that ideal society should be formed by providing a place for women to exist and develop (Hellwig, 2003:24).

She looked back at me beckoning to approach. I pretended not to understand. Instead I started watching the workers who looked amazed to see my skill. They swept, flushed the paddock floor with a long broom. All of them are women (Toer, 2003:46).

Pramoedya emphasizes it with his phrase semuanya wanita. The male jobs that he mentions are done by women. The author wants the reader to accept the reality and to understand that working women are not something common and free to find during Minke's era. Minke becomes a figure who know and understand how to place women properly.

Mother had me a seat in the back room. She sat down next to me and had me a conversation about company and trading. My knowledge about that turned out to be useless. She knew tons of Europe terms I don't understand. Instead she explained for a while like a teacher. And she could make it clear! What a Nyai beside me now? (Toer, 2003: 58).

Pramoedya encourages everyone to learn and respect anyone, even if they hold a status as a mistress or nyai. "Bumi Manusia" novel reminds readers to learn from anyone because knowledge does not have any relation with gender.

Nyai Ontosoroh figure in "Bumi Manusia" novel is an anomaly. Many novels place female characters as weak and oppressed figures. It can be seen through the female characters in "Siti Nurbaya" novel made by Marah Rusli. The figures of Siti Nurbaya and Alimah are representation of women condition who experience disparities in education. That is why education has indeed become a major focus in the feminist perspective (Soekiman, 2010: 20-21).

Although he includes gender equality in his novel, Pramoedya does not forget the nature of Nyai Ontosoroh as a woman. Implied by the quote above, nyai is still the mother of her children she is born with. Men and women are created in pairs to complement each other.

"He is a native hater, except their delight," said mother. Nothing more precious than to be European for him and all natives ought to submit him. Mother refuses to submit. He intended to take control the whole company. Everyone ought to work for him, including me and my mother (Toer, 2003:97). 
It can be seen from the quote above that Annelies explains her brother, Robert Mellema, to Minke. It is clearly illustrated in the context about a person who fights against injustice which dominates and oppresses him. Mama's resistance is illustrated by her act to reject obedience. Fighting against women injustices is one of the goals for being a feminist (Rokhmansyah, 2016:87).

Nyai Ontosoroh withstands the possibility of being oppressed, even from her own child. Eventually, she lost her fight. Being defeated with resistance is far more honorable than being defeated because of surrender.

"Your mother is merely a native woman, will not have a claim upon all also not have a claim for my own daughter, you, Ann." (Toer, 2003:112).

The struggle for women's rights is difficult when Indonesia is not yet independent. The applicable law is the law of the colonizing country which does not respect the natives. Moreover, indigenous women especially those who become mistress do not have the right to their children.

Not only that, the suppression of women's rights is not only done by the invaders, but also by the culture and the people themselves.

"Like all native women, my mother had no right to express her idea. My father was the only decision maker for all things." (Toer, 2003:119).

Parents also justify the women's right suppression to their children. This becomes a general assumption that is passed on. This is also described as a form of education so that readers must know and examine the matter of treating and respecting women in terms of their rights and obligations (Hassan, 1992:15).

Women must provide resistance to the injustices that undermine their life. Women must learn to grow independently by not being dependent on men.

All I had learned and done in the year had my dignity back. But my conviction remain. I prepared to not depend on anyone. Of course it was too overrated to a Javanese girl talked about dignity much less in that young age (Toer, 2003:130).

Women must struggle to maintain self-esteem. Through "Bumi Manusia" novel, we find that Javanese women are considered inappropriate when talking about self-esteem. This culture feels strange because it assigns women as uncivilized and disrespectful individuals. This indicates that there are still many cultures which restrain women.

Nyai Ontosoroh struggles to make her children feel brave against the blasphemers. Pramoedya illustrates fighting against women oppression and injustice as something that has longlasting effects. Eventually, it will be passed down to the children and grandchildren until it becomes a general understanding to respect women as same as men. It is a mandatory thing for a mother to prepare their children that their life are meaningful (Sartre, 2002:102).

May be Anneliese didn't engange in clapping, because she herself never went into such association. Otherwise she might lost in thought on her chair- a child who socially awkward is like a highlander kids (Toer, 2003:447).
In the quote above, the women who have never hung out are clearly illustrated. Interacting is a sign that someone is involved in socializing, being open, and seeing the outside world. The incident occurred when Annelies is brought by Minke to attend her graduation party as an HBS student Batavia.

According to this novel, women must get along and see the outside world. Therefore, women will be able to reflect and judge themselves. In Minke's era, women are always related to kitchen and household matters.

"Bumi Manusia" novel not only fights for the oppressed women rights, but also shows women's sides which are often underestimated.

Ugliness never attractive. A woman who is not able to care of her own beauty, if I were a man, I would tell my friends: don't marry such woman, she is not able to do anything, she has no ability even to care her own skin (Toer, 2003:133).

Feminists characters "Bumi Manusia" novel still maintain the things which are essential, such as preening and caring body. Pramoedya hopes that women can progress and develop by not forgetting their roots and origins. The novel also reminds us that oppression can be in an unseen form, which is why resistance must be carried out carefully and precisely (Hun, 2011:71).

"Mevrouw is not a slave. Also is not like a slave, Nyai Juffrouw," mother fixed it. "It could be a slave lives in a palace, merely a slave." (Toer, 2003:341).

Pramoedya teaches us to be aware of oppression and unfair treatment. Slaves are a sign of those whose right are oppressed and disrespected. Hence, a slave should live on freedom rather than live in an elegance.

"I just met someone, a woman you know, who won't make peace with her own fate." She took a deep breath. "And surprisingly, how she has a legal awareness is so high." (Toer, 2003:346).

Having awareness is a sign that every woman must be mindful of her rights and obligations. Awareness will encourage every woman to preserve her rights (Sugiantomas, 2015:10).

The saying of Minke's teacher, Juffrouw Magda Peters, carried forward to a compliment to Nyai Ontosoroh. "How Juffrouw belauded her." "Because she is a native, and a woman, and impressive indeed....” (Toer, 2003:348).

From the quotation above, it is written that not many women are like Nyai Ontosoroh in terms of openness and knowledge. Especially in Minke's era which is bound by patriarchal culture.

This novel encourages women, especially indigenous women, to develop themselves into strong and dignified women (Lubis, 2006:27).

Fighting is the characteristic of "Bumi Manusia" novel in every aspect and part. It is proven by Nyai Ontosoroh's and Minke's persistence to keep fighting againts any conflict.

"Even though we have no attorney. We are going to be the first native who will fight the white judiciary, son. Nyo, isn't it also an honour?" (Toer, 2003:494).

Minke and Nyai Ontosoroh put up a fight despite their lack of ideal provision to keep moving forward. This spirit of trying 
and not giving up is what "Bumi Manusia" novel tries to convey. The essence of feminism is resistance because of the unequal treatment of those who were born as women (Pujiatna, 2016:11).

"Bumi Manusia" novel ends with Pramoedya's firm attitude that human honor lies in the spirit of resistance to injustice by fighting with all efforts, respect, and the best performance.

"We have fought son, Nyo, all the best, in all respects." (Toer, 2003:535).

\section{CONCLUSION}

These are feminist ideologies according to analysis of "Bumi Manusia" novel.

First, the figures in "Bumi Manusia" novel are portrayed as critical figures who care about the fate of women. Second, women are also human beings who have the same rights as men. Third, the ideal society is formed by providing a place for women to exist and develop. Fourth, men and women are indeed created in pairs to complement each other. Fifth, women must learn to grow independently by not depending on men. Sixth, fighting oppression and injustice against women will have a long and lasting effect. Seventh, every woman must be aware of their rights and obligations as women.

To sum up, the seven feminist ideologies conveyed by Pramoedya Ananta Toer in "Bumi Manusia" novel are the foundations of gender equality education which are very suitable for character education materials to recent Indonesia generation. Eventually, women and men will be able to appreciate life more based on one's quality, not based on gender. This is where the role of literary works are able to change thought, behavior, and culture of a society and nation.

\section{ACKNOWLEDGMENT}

Thank God, the writer always prays to the Almighty God for the permission of this journal so that it can be completed in time. Thank you to:

Dr. Kastam Syamsi, M. Ed. as Chancellor of the Head of Indonesian Language and Literature Education at Postgraduate Program of UNY.

Prof. Dr. Suminto A. Sayuti and ICLLAE editorial team (International conference on interdisciplinary Language, Literature and Education). Hopefully this journal can contribute to literacy activities.

\section{REFERENCES}

Abrams, M.H. (2004). A Glossary of Literary Terms. Australia, Canada, Mexico, Singapore, and United Kingdom States: Heinle \& Heinle. Adams, Ian. (2004). Ideologi Politik Mutakhir. Yogyakarta: Qalam.

Arivia, Gadis. (2006). Feminisme Sebuah Kata Hati. Jakarta: Penerbit Buku Kompas.

Bogdan, Rand Taylor. (1993). Kualitatif: Dasar-Dasar Penelitian. (terj. Setyani. D. Sjah). Jakarta: Grasindo.

Djajanegara, Soenarti. (2000). Kritik Sastra Feminisme: Sebuah Pengantar. Jakarta: Gramedia.

Hassan, Fuad. (1992). Berkenalan dengan Eksistensialisme. Jakarta: Pustaka Jaya.

Hellwig, Tineke. (2003). Citra Perempuan dalam Sastra Indonesia. Jakarta: Women Research Institute dan Desantara.

Hollows, Joanne. (2010). Feminisme, Femininitas \& Budaya Populer. Yogyakarta: Jalasutra.

Humm, Maggie. (2007). Ensiklopedia Feminisme. Edisi Bahasa Indonesia oleh Mundi Rahayu. Yogyakarta: Fajar Pustaka Baru.

Hun, Koh Young. (2011). Pramoedya Menggugat: Melacak Jejak-Jejak Indonesia. Jakarta: Gramedia Pustaka Utama

Lubis, S. (2006). Gerakan Feminisme dalam Era Postmodernisme Abad 21. Jurnal Demokrasi, 5(1). Diunduh dalam http://ejournal.unp.ac.id/index.php/jd/article/view/1072/904

Mills, Sarra. (2009). "Teori Feminis Poskolonial" dalam Teori-Teori Feminis Kontemporer (ed. Stevi Jackson dan Jackie Jones). Yogyakarta: Jalasutra.

Owen, Nicholas. (2013). "Men and The 1970's British Women's Liberation Movement." The Historical Journal: Cambridge University Press. Diakses melalui http://journals.cambridge.org/abstract_S0018246X12000611

Pujiatna, T. (2016). “Analisis Novel Bumi Manusia Karya Pramoedya Ananta Toer dengan Kajian Feminisme.” Deiksis Jurnal Pendidikan Bahasa dan Sastra Indonesia, 3(1). Diakses melalui http://www.fkipunswagati.ac.id/ejournal/index.php/deiksis/article/view/231

Raharjo. (2010). "Pendidikan Karakter sebagai Upaya Menciptakan Akhlak Mulia", dalam Jurnal Pendidikan dan Kebudayaan, Jakarta: Balitbang Kemendiknas, Vol. 16 No. 3 Mei 2010.

Rutven, K.K. (1990). Feminist literary studies: an introduction. Cambridge: Cambridge University Press.

Rokhmansyah, Alfian. (2016). Pengantar Gender dan Feminisme: Pemahaman Awal Kritik Sastra Feminis. Yogyakarta: Garudhawaca.

Sartre, Jean Paul. (2002). Eksistensialisme dan Humanisme. Terjemahan Yudhi Murtanto. Yogyakarta: Pustaka Pelajar.

Singh, Shweta. (2007). "Deconstructing 'Gender and 'Development' for 'Identities of Women'." International Journal of Social Welfare: Cichago: Blackwell Publishing. Diakses melalui http://onlinelibrary.wiley.com/doi/10.1111/j.1468-2397.2006.00454.x/full

Soekiman, Djoko. (2011). Kebudayaan Indis: dari Zaman Kompeni sampai Revolusi. Jakarta: Komunitas Bambu.

Stanton. Robert. (2007). Teori Fiksi. Yogyakarta: Pustaka Pelajar.

Sugiantomas, A. (2015). "Analisis Tokoh Perempuan dalam Novel Bumi Manusia Karya Pramoedya Ananta Toer (Sebuah Kajian Feminisme Dilihat dari Karakter, Konflik, dan Sikap Tokoh)”. FON: Jurnal Pendidikan Bahasa dan Sastra Indonesia, 5(2). Diakses melalui https://journal.uniku.ac.id/index.php/FON/article/view/185

Sugihastuti. (2000). Kritik Sastra Feminis, Teori dan Aplikasinya. Yogyakarta: Pustaka Pelajar.

Toer, Pramoedya Ananta. (2003). Bumi Manusia. Jakarta: Lentera Dipantara.

Tong, Rosemary P. (2006). Feminist Thought. Bandung: Jalasutra.

Wellek, Rene dan Austin Warren. (2009). Teori Kesusastraan. Terj. Melani Budianta. Jakarta: Gramedia Pustaka Utama. 